\author{
Jelena Pavlović ${ }^{*}$, Tore Krogstad², Nevenka Rajić3 \\ ${ }^{1}$ University of Belgrade, Innovation Centre of the Faculty of \\ Technology and Metallurgy, Belgrade, Serbia, ${ }^{2}$ Norwegian \\ University of Life Sciences, Faculty of Environmental Science \\ and Technology, Norway, ${ }^{3}$ University of Belgrade, Faculty of \\ Technology and Metallurgy, Belgrade, Serbia
}

Scientific paper ISSN 0351-9465, E-ISSN 2466-2585 UDC:549.67:631.416.2 doi:10.5937/ZasMat1604539P

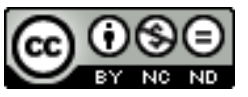

Zastita Materijala 57 (4) $539-544$ (2016)

\title{
Influence of the Fe(III)-modified clinoptilolite on phosphorus leaching from different soil types
}

\begin{abstract}
Influence of the iron(III)-modified clinoptilolite (FeCLI) on phosphorus leaching from two different Norwegian soil types (sand and clay loam soil) was studied using a column system at room temperature. FeCLI was used in different amounts of 0.5, 1.5 and 2.5 wt. \%. The obtained results indicate that the presence of FeCLI causing a reduction of phosphorus leaching from both soil types. The reduction efficiency increases with the FeCLI amount. Addition of $2.5 \mathrm{wt} \% \mathrm{FeCLI}$ to the soils decreased the phosphorus leaching by $48 \%$ from clay loam soil and by $42 \%$ from sand soil compared to the control systems. FeCLI also increased $\mathrm{pH}$ of the soils from 5.1 to 7.0 for sand and from 5.7 to 7.7 for clay loam soil. All obtained results indicate that FeCLI is a promising soil supplement for the studied soil types due to phosphorus preservation and a decrease of soil acidity.

Keywords: phosphorus, soil, phosphorus leaching, eutrophication, natural zeolite, ironclinoptilolite.
\end{abstract}

\section{INTRODUCTION}

Natural zeolites are crystalline, hydrated aluminosilicates widely used in ion-exchange, adsorption and catalytic reactions due to their unique physical and chemical properties. Being inexpensive, nontoxic and environmental-friendly minerals, natural zeolites have been used in agriculture as soil amendments and fertilizers. Generally, addition of zeolites to soil can increase retention of plant nutrients in the root zone and prevent their leaching through the soil [1-3]. Moreover, many studies have reported the use of natural zeolites in remediation of contaminated soils showing a crucial role of zeolites in the capture of $\mathrm{Pb}, \mathrm{Zn}$ and $\mathrm{Cd}$ and prevention of plant systems to uptake these toxic metal cations [4-6]. Also, zeolites have a positive role in improving the agricultural production (yield and quality of crops) of sunflower [7], maize [8, 9], spring wheat [10], rice [11] and lettuce [12].

\footnotetext{
*Corresponding author: Jelena Pavlović

E-mail: jelena.pavlovic@tmf.bg.ac.rs

Paper received: 04. 07. 2016.

Paper accepted: 15. 08. 2016.

Paper is available on the website: www.idk.org.rs/journal
}

In agricultural practice, there has been an increasing interest for soil amendments which not only improve agicultural production but also prevent degradation of groundwater quality through nutrients leaching. Thus, phosphorus is an essential plant nutrient but it is also resposonsible for eutrophication of water bodies. Some agricultural areas are particularly vulnerable because of the excessive leaching of phosphorus. These areas usually receive an excessive amounts of phosphorus due to soil type and are prone to erosion and leaching.

Taking this into account the present study has two general aims: 1) to investigate the influence of addition of the iron(III)-modified natural zeolite clinoptilolite on the phosphorus leaching from two different soil types, and 2) to study the influence of the zeolite on soil pH. Since the as-received natural zeolites have no affinity towards anions because of the negatively charged aluminosilicate lattice, the zeolite was previously modified with iron(III) in order to obtain an iron oxide coating which has been known to readily adsorb phosphates [13-15].

\section{EXPERIMENTAL}

\subsection{Preparation of the FeCLI}

The zeolitic tuff (CLI) used in this study was provided from Iran (Semnam mine). The tuff contained about 90 wt.\% of clinoptilolite and quartz 
and feldspars as major impurities. Prior to the experiments the as-received sample was sieved and washed with deionized water. Particle size in the range of $0.063-0.125 \mathrm{~mm}$ was chosen for the experiments.

FeCLI was prepared as follows. The CLI sample $(10.00 \mathrm{~g})$ was suspended in $400 \mathrm{~cm}^{3}$ of $0.05 \mathrm{~mol} \mathrm{dm}{ }^{-3} \mathrm{Fe}_{2}\left(\mathrm{SO}_{4}\right)_{3}$ in an acetate buffer $(\mathrm{pH}=$ 3.6). Then the $\mathrm{pH}$ of the suspension was adjusted to 7 using $\mathrm{NaOH}$ solution and the suspension was magnetically stirred for $24 \mathrm{~h}$ at $70 \stackrel{\circ}{ } \mathrm{C}$. After filtering, the obtained product was washed with deionized water until a negative reaction for sulfate ions and then dried at $90^{\circ} \mathrm{C}$ to a constant mass.

\subsection{Characterization of the zeolite samples}

\subsubsection{Chemical analysis}

Elemental composition of the samples was obtained by an energy dispersive X-ray spectroscopy (EDS) using a scanning electron microscope (SEM, Jeol, JSM-6610LV). In order to obtain elemental composition of the clinoptilolite phase an intersection view of the crystallite grains was prepared. The procedure consisted of embedding grains in an epoxy film, polishing the crystallites, cutting them with a fine-grid diamond cutter and coating them with gold.

\subsubsection{X-ray diffraction}

Crystallinity of the samples was checked at room temperature by a powder X-ray diffraction analysis (PXRD) using APD2000 Ital Structure diffractometer with CuKa radiation $(\lambda=0.15418$ $\mathrm{nm}$ ). Prior to analysis the samples were thoroughly homogenized in an agate mortar. The data were collected in the $2 \theta$ range of $5-50^{\circ}$ with a step $0.02^{\circ}$ $\mathrm{s}^{-1}$ and with a scan step time of $0.5 \mathrm{~s}$.

\subsubsection{Thermal analysis}

Thermal analysis was used for the determination of water content. The analysis was conducted using a SDT Q600 simultaneous TGADTA instrument (TA Instruments). The samples were heated from the room temperature to $800^{\circ} \mathrm{C}$, at a heating rate of $10^{\circ} \mathrm{C} \mathrm{min}^{-1}$ under air (flow rate of $100 \mathrm{ml} \mathrm{min}^{-1}$ ).

\subsubsection{Textural characteristics}

The specific surface area and porosity of zeolite samples were determined by the $\mathrm{N}_{2}$-BET adsorption method (Micromeritics ASAP 2020) at $196^{\circ} \mathrm{C}$. Prior to the measurements the samples were degassed under vacuum at $150{ }^{\circ} \mathrm{C}$ for 10 hours. The specific surface area was obtained according to the BET (Brunauer, Emmett, Teller) method The total pore volume was determined from the desorption isotherm at $p / p_{0}=0.998$. The pore size distribution was determined using the BJH method (Barrett, Joyner and Halenda).

\subsection{Soil samples characterization}

The soil samples were collected from Norway (59 $39^{\prime} 47^{\prime \prime} \mathrm{N}$ and $\left.10^{\circ} 45^{\prime} 42^{\prime \prime} \mathrm{E}\right)$. The samples were air dried, sieved $(2 \mathrm{~mm})$ and stored in polyethylene bags. According to the World Reference Base [16] the sample containing (wt.\%) clay - 25 , silt - 40 and sand - 35 is classified as clay loam type whereas the other one containing (wt.\%) sand - 94 , clay - 3 and sand - 3 belongs to sand soil type.

Selected physico-chemical properties of the soil samples were determined by standard procedures. Soil $\mathrm{pH}$ was measured in distilled water (with a soil to solution ratio of $1: 2.5$ ). The content of organic matter (OM) was determined as the loss on ignition at $550^{\circ} \mathrm{C}$. Concentration of the plant available phosphorus was determined by the Egners Al-method [17]. The measurements were done by extracting the soil sample with an ammonium lactate solution and phosphorus content in the solution was determined colorimetrically using the molybdenum-blue method [18].

\subsection{Leaching experiments}

The leaching experiments were conducted at room temperature using a column system (Figure 1).

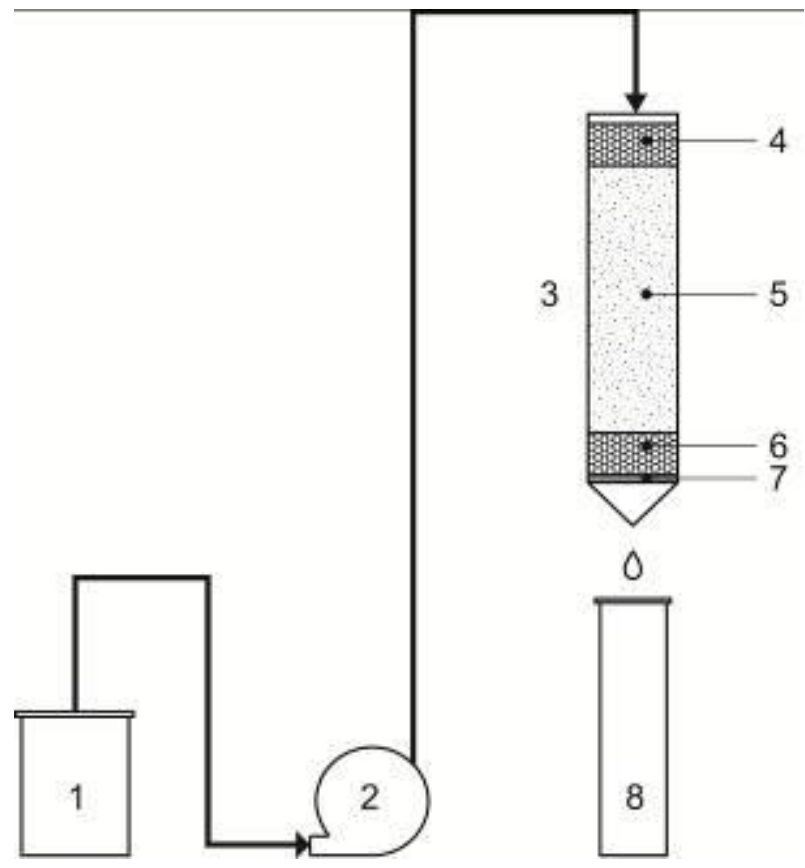

Figure 1 - The experimental setup for leaching experiments: (1) water tank; (2) peristaltic pump; (3) plexiglass column; (4) PVC balls; (5) soil or soil/FeCLI mixture; (6) PVC balls; (7) PVC filter; (8) sample collector

The plexiglass columns of $24 \mathrm{~mm}$ in diameter and $30 \mathrm{~cm}$ long were organized in the following systems with three replications of each: A (only 
soil, Control), B (Soil + 0.5 wt.\% FeCLI), C (Soil + 1.5 wt.\% FeCLI) and D (Soil + 2.5 wt.\% FeCLI).

Amounts of the added FeCLI corresponded to about 10,30 and $50 \mathrm{t} \mathrm{FeCLI} \mathrm{ha}{ }^{-1}$, respectively. Prior to filling the columns, mixtures of soil and FeCLI were homogenized in a rotating shaker overnight. Then, each column was filled up to a 20 $\mathrm{cm}$ height with the soil or soil/FeCLI mixture. To prevent loss of soil from the columns the bottom of the columns was covered with a PVC filter and PVC balls (about $2 \mathrm{~cm}$ in height). Also, the top of each column was covered with the balls in order to provide an effective distribution of water.

During the leaching experiments the filled columns were saturated and then irrigated with distilled water. To simulate the effect of heavy precipitation on the phosphorus leaching, the water flow was for a short time period about $1.3 \mathrm{ml} \mathrm{h}^{-1}$ (500 $\mathrm{mm}$ of precipitation during 7 days). The leaching experiments were performed in the absence of light.

\subsection{Leachate analyses}

The leachates were collected at the column bottom every day for seven days (or twelve days for sand soil). The P concentration in the collected leachates was determined collorimetrically, using the molybdenum-blue method [18].

\subsection{1 pH analysis of leachates}

At the end of leaching experiments, $\mathrm{pH}$ of leachates (collected during the last day of the leaching experiment) was measured (Orion SA720).

\section{RESULTS AND DISCUSSION}

\subsection{Characterization of the zeolite samples}

Elemental analysis of the clinoptilolite phase in $\mathrm{CLI}$ and FeCLI is given in Table 1. For both samples the $\mathrm{Si} / \mathrm{Al}$ molar ratio of about 5 proves the presence of the clinoptilolite mineral phase. The ratio is significantly lower for feldspars being in the range of 2.5-2.7 [19]. It is also evident that the modification of CLI led to a significant increase of the Fe content (from 0.75 to 17.2 at. \%).

Table 1 - Elemental composition of the clinoptilolite phase obtained by EDS analysis

\begin{tabular}{|c|c|c|c|c|c|c|c|c|}
\hline \multirow{2}{*}{ Sample } & \multicolumn{8}{|c|}{ at.\% } \\
\hline & $\mathrm{O}$ & $\mathrm{Na}$ & $\mathrm{Mg}$ & $\mathrm{Al}$ & Si & K & $\mathrm{Ca}$ & $\mathrm{Fe}$ \\
\hline CLI & 55.0 & 0.90 & 0.73 & 6.34 & 32.3 & 1.33 & 2.30 & 0.75 \\
\hline FeCLI & 45.3 & 2.32 & 0.29 & 5.26 & 27.7 & 1.19 & 0.73 & 17.2 \\
\hline
\end{tabular}

The PXRD patterns of samples given in Fig. 2 show that the zeolitic tuff is rich in the clinoptilolite phase and that quartz and feldspars are the major satellite minerals. It is also evident that the crystallinity of the clinoptilolite remains unaffected after the modification and that no crystalline iron oxide phase is present.

Figure 3 shows the TG/DTG curves indicating a rather continuous water release. It is evident that water content increases by the modification from 10.5 wt.\% (CLI) to 13.5 wt.\% (FeCLI) which could be attributed to the formation of hydrous iron oxide species.

The modification significantly affects the specific surface area and porous characteristics of the clinoptilolite phase (Table 2). The specific surface area increases from 29 to $140 \mathrm{~m}^{2} \mathrm{~g}^{-1}$ and the total pore volumes from 0.1045 to $0.2460 \mathrm{~cm}^{3}$ $\mathrm{g}^{-1}$. The change suggests formation of a secondary pore structure at the clinoptilolite surface during modification. Namely, flaky amorphous hydrous iron oxide precipitate has been detected by a TEM analysis (data not given).

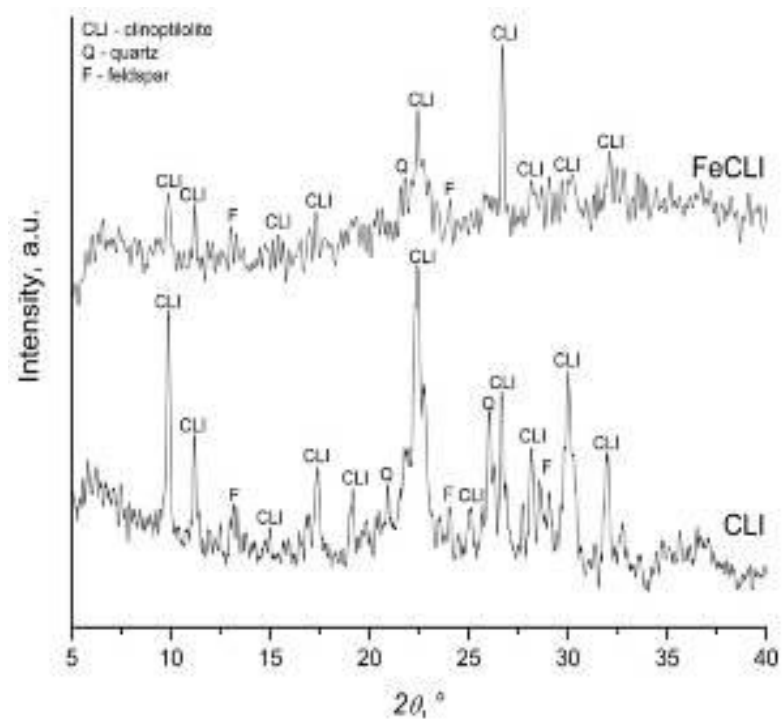

Figure 2 - PXRD patterns of the zeolite samples 

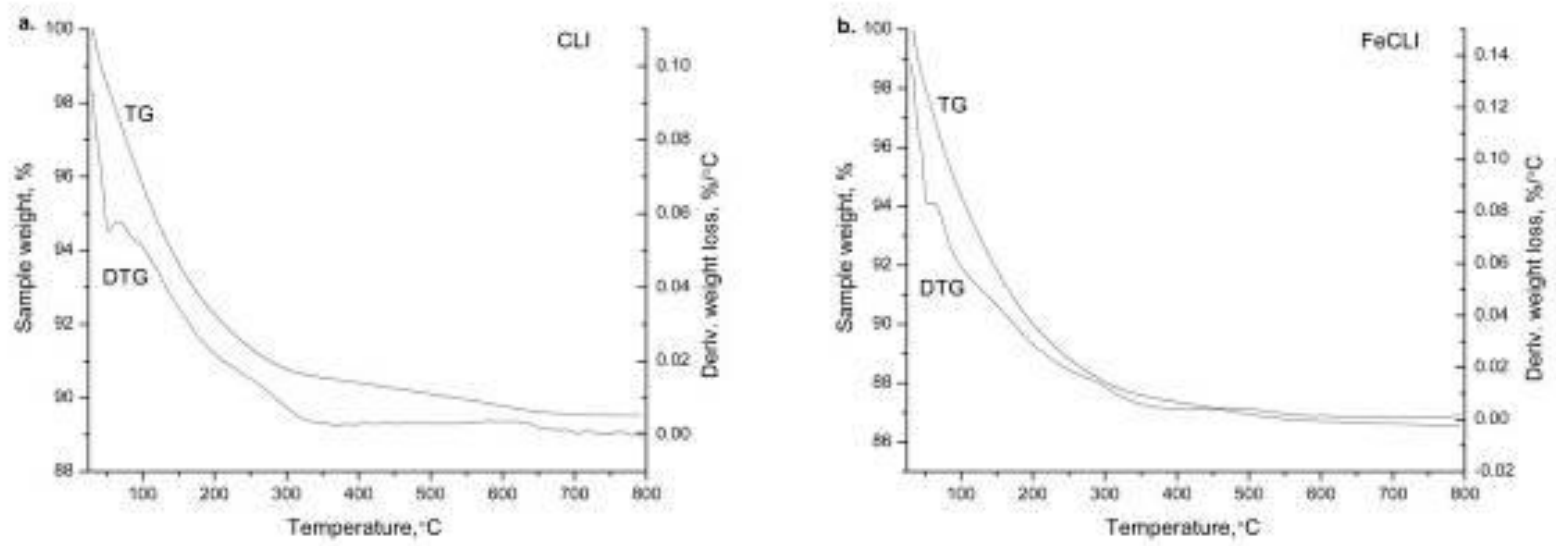

Figure 3 - TG/DTG curves of CLI (a) and FeCLI (b)

Table 2 - Textural properties of the zeolite samples

\begin{tabular}{|c|c|c|c|c|}
\hline Sample & $\mathrm{S}_{\text {BET }}, \mathrm{m}^{2} \mathrm{~g}^{-1}$ & $\mathrm{~V}_{\text {tot }}, \mathrm{cm}^{3} \mathrm{~g}^{-1}$ & $\mathrm{~V}_{\text {meso }}, \mathrm{cm}^{3} \mathrm{~g}^{-1}$ & $\mathrm{~V}_{\text {micro }}, \mathrm{cm}^{3} \mathrm{~g}^{-1}$ \\
\hline $\mathrm{CLI}$ & 29 & 0.1045 & 0.1026 & 0.0095 \\
\hline $\mathrm{FeCLI}$ & 140 & 0.2460 & 0.2340 & 0.0431 \\
\hline
\end{tabular}

\subsection{Soil characterization}

Both soil samples are acidic with $\mathrm{pH}=5.1$ (sand soil) and 5.7 (clay loam). Their other physicochemical properties depend on the soil type. Sand soil is poor with the OM content (1.3 wt.\%) compared to the clay loam soil (5.7 wt.\%). Also, the sand soil has a significantly lower content of the plant available $\mathrm{P}\left(16 \mathrm{mg} \mathrm{kg}^{-1}\right)$ than clay loam soil (179 $\mathrm{mg} \mathrm{kg}^{-1}$ ).

\subsection{Leaching experiments}

The results of the leaching experiments are presented as breakthrough curves (the presented graphs show relationships between phosphorus concentration in collected samples over time).

Comparing the phosphorus amount leached from the soil samples (Figures 4 and 5), it is evident that the phosphorus leaching is significantly higher from clay loam than from sand soil for all the analyzed systems. This could be ascribed both to a high phosphorus content as well as to a low adsorption capacity of clay loam soil. It is probable that the phosphorus adsorption sites on the clay loam soil particles are already occupied and not available for adsorption. Moreover, the total amount of phosphorus collected in leachates from the clay loam soil (system A) was about $0.2 \mathrm{mg} \mathrm{P}$ $\mathrm{dm}^{-3}$ (Figure 4). Addition of FeCLI to this soil reduces the phoshporus leaching and the effect increases with the rise in the FeCLI amount. The rise in the $\mathrm{FeCLI}$ amount from 0.5 to $1.5 \mathrm{wt} \%$ (systems B and C, respectively) increases efficiency by about six times (the phosporus leaching reduces for 3.5 and $22.5 \%$, respectively) whereas the highest applied amount (2.5 wt.\% FeCLI, system D, Fig. 4) reduces the phosphorus leaching for $48 \%$.

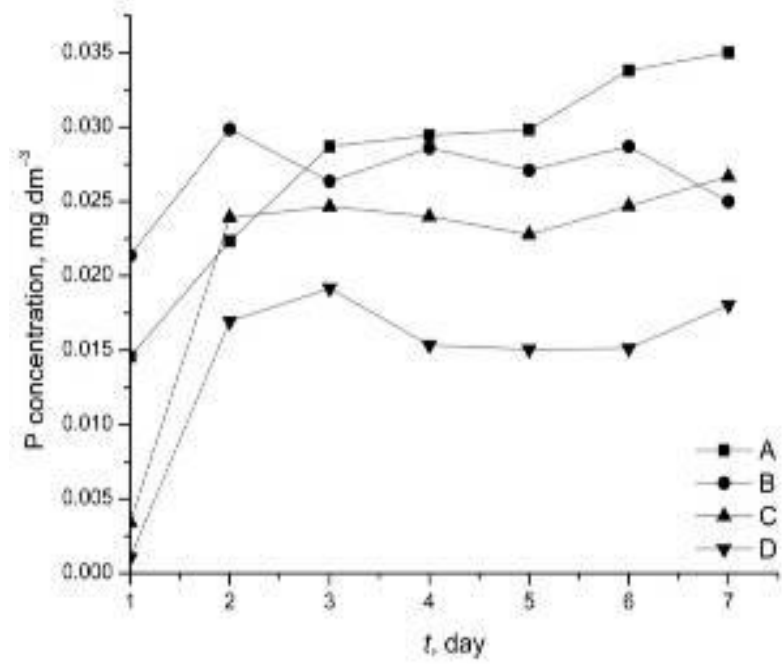

Figure 4 - The phosphorus concentration in leachates collected from clay loam soil ( $A$ - Soil; $B$ Soil + $0.5 w t$. \% FeCLI; C - Soil + $1.5 w t . \%$ FeCLI; D - Soil + $2.5 w t . \%$ FeCLI)

The reduction the phosphorus leaching from the sample of sand soil contained FeCLI is also evident. The leaching experiment for this systems was conducted longer (twelve days instead of seven) since the leached amount of phosphorus was very low and almost constant during seven 
days (Figure 5). In order to examine the effect of the FeCLI addition to the sand soil, powdered $\mathrm{KH}_{2} \mathrm{PO}_{4}$ (in an amount equal to $300 \mathrm{~kg} \mathrm{P} \mathrm{ha}{ }^{-1}$ ) was added to the columns containing sand soil after seven days. The addition of $\mathrm{KH}_{2} \mathrm{PO}_{4}$ caused an increase in the phosphorus leaching. The total amount of the leached phosphorus was $0.0048 \mathrm{mg}$ $\mathrm{dm}^{-3}$ and the presence of FeCLI in the sand soil reduces the phosphorus leaching. Similarly to the clay loam soil case, the effect depends on the FeCLI amount. An increase of the FeCLI amount from 0.5 to 1.5 wt.\% (systems $B$ and $C$, respectively) increases efficiency by about six times (the phosporus leaching reduces for $4 \%$ and $25 \%$, respectively), whereas the highest applied amount (2.5 wt.\% FeCLI, system D, Fig. 5) reduces the phosphorus leaching for $42 \%$.

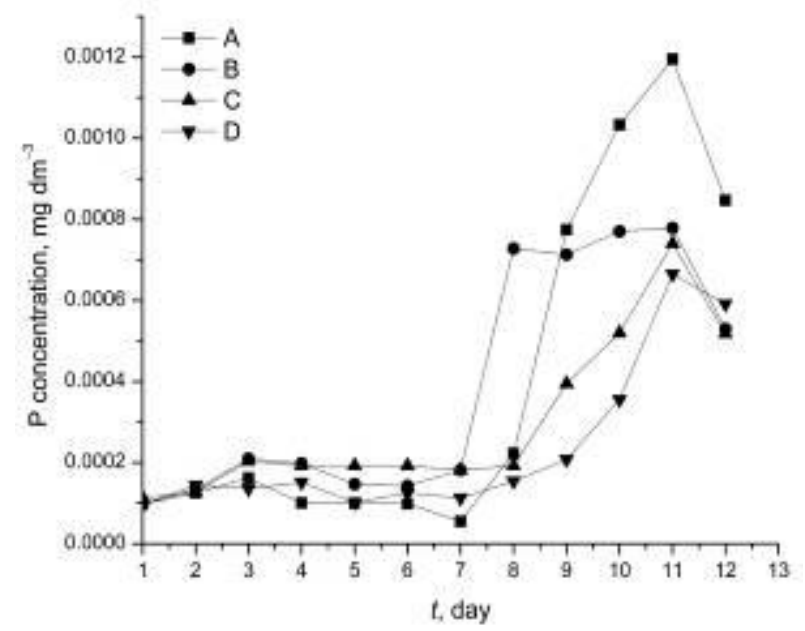

Figure 5 - Posphorous concentration of in the collected samples from sand soil ( $A$ - Soil; $B$ - Soil + 0.5 wt.\% FeCLI; C - Soil + 1.5 wt. \% FeCLI; D Soil + $2.5 w t$ \% FeCLI)

The effect of FeCLI on the phosphorus preservation in the examined soil samples could be ascribed to its unique physico-chemical properties. Firstly, FeCLI has a high specific surface (five times higher than the parent zeolite) which significantly improves the adsorption capacity of the zeolite. Secondly, in contrast to the CLI itself, FeCLI possesses the phosphorus adsorption sites which prevent phosphorus leaching. Finally, addition of FeCLI to the soils probably affects the physical and hydraulic properties of soils [2].

\subsection{1. $\mathrm{pH}$ analysis}

The addition of FeCLI to both soil types decreases their acidity (Figure 6). A degree of efficiency is similar for both analyzed soils. The addition of 2.5 wt. \% FeCLI increases $\mathrm{pH}$ value from 5.7 to 7.7 for clay loam and from 5.1 to 7.0 for sand soil.

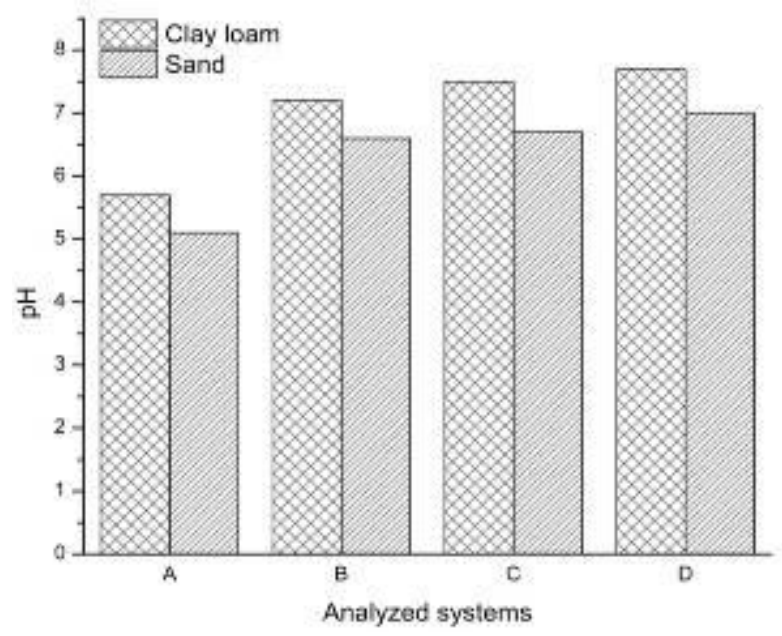

Figure 6 - Influence of the FeCLI addition on the soil pH (A - Soil; B - Soil + 0.5 wt. \% FeCLI; $C$ - Soil + 1.5 wt. \% FeCLI; D - Soil + 2.5 wt.\% FeCLI)

The obtained results are especially important for sandy soils which are generally infertile and require special treatments to reduce acidity [20].

\section{CONCLUSION}

The presented results show that the iron(III)modified clinoptilolite is a promising soil supplement. It is effective in the reduction of phosphorus leaching from both the clay loam and the sand soil types. Its use at the rate of $2.5 \mathrm{wt} \%$ reduces the phosphorus leaching for $42-48 \%$ depending on the soil types. It also decreases the soil acidity which is one of the most important prerequisites for a high crop production. Finally, the obtained results indicate that natural zeolites after a slight modification could find wide use in the agricultural practice.

\section{Acknowledgements}

This research was supported by the Ministry of Education, Science and Technological Development of the Republic of Serbia (Project No. 172018) and HERD project ("The use of natural zeolite (clinoptilolite) for treatment of farm slurry and as a fertilizer carrier") financed by the Norwegian Ministry of Foreign Affairs. The authors acknowledge to the company "Zeodigest" from Iran which kindly provided the natural zeolitic sample for this research.

\section{REFERENCES}

[1] H.W.Pickering, N.W.Menzies, M.N.Hunter (2002) Zeolite/rock phosphate-a novel slow release phosphorus fertilizer for potted plant production, Scientia Horticulturae, 94, 333-343.

[2] N.Colombani, M.Mastrocicco, D.Di Giuseppe, M. Coltorti (2015) Batch and column experimemnts on nutrient leaching in soils amended with Italian natural zeolites, Catena, 127, 64-71. 
[3] R.Malekian, J.Abedi-Koupai, S.S.Eslamian (2011) Influences of clinoptilolite and surfactant-modified clinoptilolite zeolite on nitrate leaching and plant growth, Journal of Hazardous Materials, 185, 970976

[4] W.Shi, H.Li, S.Du, K.Wang, H.Shao (2013) Immobilization of lead by application of zeolite: Leaching column and rhizobox incubation studies, Applied Clay Science, 85, 103-108.

[5] H.Li, W.Shi, H.Shao, M.Shao (2009) The remediation of the lead-polluted garden soil by natural zeolite, Journal of Hazardous Materials, 169, 1106-1111.

[6] A.Moirou, A.Xenidi, A.Paspaliaris (2001) Stabilization $\mathrm{Pb}, \mathrm{Zn}$, and $\mathrm{Cd}$ contaminated soil by means of natural zeolite, Soil and Sediment Contamination, 10, 251-267.

[7] M.Gholamhoseini, A.Ghalavand, A.KhodaeiJoghan, A.Dolatabadian (2013) Zeolite-amended cattle manure effects on sunflower yield, seed quality, water use efficiency and nutrient leaching, Soil \& Tillage Research, 126, 193-202.

[8] O.H.Ahmed, G.Sumalatha, A.M.Nik Muhamed (2010) Use of zeolite in maize (Zea mays) cultivation on nitrogen, potassium and phosphorus uptake and use efficiency, International Journal of the Physical Sciences, 5, 2393-2401.

[9] J.A.Ippolito, D.DTarkalson, G.A.Lehrsch (2011) Zeolite soil application method affects inorganic nitrogen, moisture and corn growth, Soil science, $176,136-142$

[10] P.J.Leggo (2000) An investigation of plant growth in an organo-zeolitic substrate its ecological significance, Plant and Soil, 219, 135-146.

[11] A.Sepaskhah, M.Barzegar (2010) Yield, water and nitrogen-use response of rice to zeolite and nitrogen fertilization in a semi-arid environment, Agricultural Water Management, 98, 38-44.
[12] A.Gül, D.Eroğul, A.R.Ongun (2005) Comparison of the use of zeolite and perlite as substrate for crisphead lettuce, Scientia Horticulture, 106, 464-471.

[13] L.Gan, J.Zuo, B.Xie, P.Li, X.Huang (2012) Zeolite (Na) modified by nano-Fe particles adsorbing phosphate in rainwater runoff, Journal of Environmental Sciences, 24(11), 1929-1933.

[14] K.S.Kim, J.O.Park, S.C.Nam (2013) Synthesis of iron-loaded zeolites for removal of ammonium and phosphate from aqueous solutions, Environmental Engineering Research, 18(4), 267-276.

[15] D.Guaya, C.Valderrama, A.Farran, J.L.Cortina (2015) Modification of a natural zeolite with $\mathrm{Fe}(\mathrm{III})$ for simultaneous phosphate and ammonium removal from aqueous solutions, Journal of Chemical Technology and Biotechnology, 91(6) 1737-1746.

[16] World reference base for soil resources 2014 (2015) Food and Agriculture Organization of the United Nations, Rome.

[17] H.Egner, H.Riehm, W.R.Domingo (1960) Untersuchungen über die chemische Bodenanalyse als Grundlage für die Beurteilung des Nahrstoffzustandes der Boden, II: Chemische Extractionsmetoden zu Phosphorund Kaliumbestimmung, Kungliga Lantbrukshügskolans Annaler, 26, 199-215.

[18] J.Murphy, J.P.Riley (1962) A modified single solution method for the determination of phosphates in natural water, Analytica Chimica Acta, 27, 31-36.

[19] A.Godelitsas, T.Armbruster (2003) HEU-type zeolites modified by transition elements and lead, Microporous and Mesoporous Materials, 61, 3-24.

[20] T.Andronikashvili, M.Zautashvili, L.Eprikashvili, N Burkiashvili, N. Pirtskhalava (2012) Natural zeolite One of the possibilities of transition from chemical to biological agronomy, Bulletin of the Georgian National Academy of Sciences, 6(2), 111-118.

\section{IZVOD}

\section{UTICAJ Fe(III)-MODIFIKOVANOG KLINOPTILOLITA NA IZLUŽIVANJE FOSFORA IZ RAZLIČITIH VRSTA ZEMLJIŠTA}

$U$ radu je ispitivan uticaj gvožđe(III)-modifikovanog klinoptilolita (FeCLI) na izluživanje fosfora iz dve različite vrste norveškog zemljišta (pesak i glinovita ilovača). Eksperimenti su izvedeni u kolonama na sobnoj temperaturi. FeCLI je dodavan u različitim koncentracijama 0,5; 1,5 i 2,5 mas. \%. Dobijeni rezultati ukazuju da FeCLI doprinosi smanjenju izluživanja fosfora kako iz peskovitog, tako i iz glinovito ilovačastog zemljišta. Efikasnost FeCLI raste sa povećanjem koncentracije FeCLI u zemljištu. U koncentraciji 2,5 mas.\% FeCLI smanjuje izluživanje fosfora za $48 \%$ (iz glinovite ilovače) i 42 \% (iz peskovitog zemljišta). Takođe, FeCLI povećava pH zemljišta: od 5,1 do 7,0 (pesak) i 5,7 do 7,7 (glinovita ilovača). Dobijeni rezultati ukazuju da je FeCLI perspektivan suplement koji doprinosi zadržavanju fosfora u zemljištu i smanjenju kiselosti obe vrste ispitivanih zemljišta.

Ključne reči: fosfor, zemljište, izluživanje fosfora, eutrofikacija, prirodni zeolit, gvožđe-klinoptilolit.

Naučni rad

Rad primljen: 04. 07. 2016.

Rad prihvaćen: 15. 08. 2016.

Rad je dostupan na sajtu: www.idk.org.rs/casopis 